\title{
Tatalaksana Anestesi pada Operasi Obstetri dengan Covid-19
}

\author{
Isngadi $^{1}$, Rafidya Indah Septica ${ }^{2}$, Susilo Chandra ${ }^{3}$ \\ ${ }^{1}$ Departemen Anestesiologi \& Terapi Intensif Fakultas Kedokteran Universitas Brawijaya-Rumah Sakit Dr Safiul \\ Anwar Malang, ${ }^{2} \mathrm{KSM}$ Anestesiologi RSU Kabupaten Tangerang, ${ }^{3}$ Departemen Anestesiologi \& Terapi Intensif \\ Fakultas Kedokteran Universitas Indonesia-Rumah Sakit Cipto Mangunkusumo Jakarta.
}

\begin{abstract}
Abstrak
Coronavirus Disease 2019 (COVID-19) merupakan masalah utama kesehatan dunia. Kasus COVID-19 terus meningkat secara ekponensial di berbagai belahan dunia. Wanita hamil juga mengalami peningkatan kejadian infeksi COVID-19. Manifestasi klinis COVID-19 bervariasi, dengan sebagian besar pasien memiliki gejala saluran pernapasan. Pasien terinfeksi covid-19 yang asimpomatis atau pasien yang terinfeksi sebelum munculnya manifestasi klinis mampu menularkan penyakit. Sehingga perlu dilakukan deteksi dini kepada semua maternal yang akan dilakukan tindakan operasi, terutama di daerah dengan kejadian inveksi COVID-19 yang tinggi. Tatalaksana anestesi pada operasi obstetri dengan COVID-19 harus memperhatikan beberapa hal dengan tujuan pengendalian infeksi untuk mencegah penularan COVID-19, kepada petugas kesehatan, anak yang baru dilahirkan serta orang lain lingkungan sekitar. Tenaga kesehatan yang terpapar COVID-19 berisiko terinfeksi apabila tidak menggunakan alat pelindung diri (APD) sesuai standar, sehingga penggunaan APD sesuai standart secara benar sangat penting, untuk mencegah tertularnya COVID-19 pada petugas. Tehnik anestesi yang menjadi pilihan utama untuk operasi obstetri dengan COVID-19, adalah dengan tehnik anestesi regional (epidural dan atau spinal), karena dengan tehnik tersebut mengindari timbulnya aerosol. Tehnik anestesi umum hanya digunakan apabila : gagal dengan tehnik anestesi regional, ada kontraindikasi dengan tehnik anestesi regional atau maternal mengalami desaturasi(saturasi $<93 \%$ ). Apabila menggunakan tehnik anestesi umum maka dalam pelaksanaanya harus dengan prinsip pencegahan terjadinya penyebaran infeksi.
\end{abstract}

Kata kunci: anestesi; COVID-19; operasi obstetri

\section{Anesthesia Management for obstetric surgery with COVID-19 infected}

\begin{abstract}
The coronavirus disease 19 (COVID-19) is a global health problem. The number of cases of COVID-19 continue to rise exponentially in many parts of the world. Pregnant women have also increasing COVID-19 infection. The clinical manifestations of COVID-19 are varied, with most patients having respiratory symptom. The asymptomatic covid-19 infected patients or infected patients before clinical manifestations can transmit the disease. So early detection should be done for all mothers who will perform surgery, especially in areas with a high incidence of COVID-19 infection. Anesthesia management in obstetric surgery with COVID-19 must pay attention to several things with the aim of controlling infection to prevent transmission of COVID-19, for health workers, newborn babies and other people in the surrounding environment. Health workers who are exposed to COVID-19 are at risk of infection if they do not use personal protective equipment (PPE) according to the standard, so the use of PPE according to proper standards is very important, to prevent the transmission of COVID-19 to the officerExpected health workers, COVID-19, the risk of coverage, do not use personal protective equipment (PPE) according to standards, so the use of PPE according to the standard, is very important. The first choice of Anesthesia techniques for obstetric surgery in maternal COVID-19 infection are regional anesthesia techniques (epidural and or spinal), because with these techniques avoid the emergence of aerosols. General anesthesia techniques are only used if: fail with regional anesthesia techniques, there are contraindications to regional anesthesia or maternal desaturation (saturation <93). If using general anesthesia techniques, the prevention of infection is a major concern
\end{abstract}

Key words: anesthesia; COVID-19; obstetric surgery 


\section{Pendahuluan}

Coronavirus Disease 2019 (COVID-19) merupakan masalah kesehatan dunia. Pada tanggal 31 Desember 2019, World Health Organization (WHO) pertama kali menyebutkan bahwa adanya kasus kluster pneumonia dengan etiologi yang tidak jelas di Kota Wuhan, Provinsi Hubei, China1. Kasus ini bertambah parah hingga pada tanggal 6 Januari 2020, para ilmuwan Cina mengonfirmasi bahwa outbreak tersebut disebabkan oleh novel coronavirus, yang awalnya disebut sebagai 2019-nCoV.3 Baru-baru ini, 2019-nCoV berganti nama menjadi severe acute respiratory syndrome-related coronavirus 2 (SARS-CoV-2), dan sekarang disebut coronavirus disease 2019 (COVID-19) oleh WHO.3 Sampai akhirnya COVID-19 dinyatakan sebagai pandemik oleh WHO pada tanggal 11 Maret 2020 karena penyebarannya yang cepat ke seluruh dunia. ${ }^{4}$ Presiden Republik Indonesia telah menyatakan status penyakit ini menjadi tahap Tanggap Darurat pada tanggal 16 Maret 2020. ${ }^{5}$ Manifestasi klinis COVID-19 bervariasi, dengan sebagian besar pasien memiliki gejala saluran pernapasan.

Penelitian pada 1.099 pasien COVID-19 menunjukkan bahwa $19 \%$ pasien mengalami sesak napas, $41 \%$ membutuhkan suplementasi oksigen, 5\% menjadi sakit kritis, dan 2,3\% membutuhkan ventilasi mekanik invasif. Pasien yang terinfeksi COVID-19 berisiko mengalami gagal napas, sehingga perlu untuk dirawat di cricital care unit. Terdapat laporan yang belum terkonfirmasi bahwa penularan dapat terjadi sebelum munculnya manifestasi klinis, sehingga sulit untuk mengidentifikasi dan mengisolasi pasien yang terinfeksi COVID-19. ${ }^{4}$ Dokter anestesi sebagai garda terdepan dalam penatalaksanaan pasien Covid-19, yang dimulai sejak pasien datang ke rumah sakit, di kamar operasi dan juga sebagai benteng pertahanan terakhir di critical care unit diharapkan mampu melakukan penyesuaian tindakan anestesi pada setiap pasien dan mempraktikkan pengendalian infeksi dalam anestesi, khususnya di era penyakit menular dan patogen yang baru muncul saat ini. Selama memberikan perawatan yang optimal untuk pasien COVID-19, dokter anestesi harus selalu melaksanakan langkah-langkah pengendalian infeksi untuk mencegah penularan nosokomial ke pasien lain dan tenaga kesehatan yang juga merawat pasien.

\section{Coronavirus Disease 2019 (COVID-19)}

Coronavirus adalah keluarga besar virus yang menyebabkan penyakit mulai dari gejala ringan sampai berat. $^{4}$ Coronavirus Disease 2019 (COVID-19) merupakan penyakit jenis baru yang belum pernah diidentifikasi sebelumnya pada manusia. ${ }^{1}$ Coronavirus termasuk zoonosis atau virus yang ditularkan antara hewan dan manusia. ${ }^{5}$ Padamanusia, coronavirus biasanya menyebabkan penyakit infeksi saluran pernapasan, mulai flu biasa hingga penyakit yang serius seperti Middle East Respiratory Syndrome (MERS) dan Severe Acute Respiratory Sundrome (SARS). ${ }^{7}$ Tanda dan gejala umum infeksi COVID-19 antara lain gejala gangguan pernapasan akut seperti demam, batuk, dan sesak napas1 Penyakit ini terutama menyebar dari orang ke orang melalui droplet saat batuk dan bersin. ${ }^{8}$ Virus ini dapat bertahan hingga 3 hari dalam plastik atau stainless steel dan 3 jam pada aerosol.

Organ yang paling dipengaruhi oleh COVID-19 adalah paru, karena virus mengakses sel inang melalui enzin ACE2 yang paling banyak pada sel alveolar tipe II paru. ${ }^{7}$ Virus ini menggunakan glikoprotein permukaan khusus yang disebut "spike" untuk terhubung ke ACE2 dan memasuki sel inang. Kepadatan ACE2 di setiap jaringan berkorelasi dengan tingkat keparahan penyakit di jaringan tersebut, sehingga beberapa ahli berpendapat bahwa penurunan aktivitas ACE2 mungkin bersifat protektif. $^{6}$ Seiring dengan perkembangan penyakit alveolar, infeksi ini mungkin dapat menyebabkan gagal napas dan bahkan kematian.

\section{Skrining}

Kegiatan skrining kasus COVID-19 wilayah dilakukan melalui penemuan orang sesuai dengan status pasien. Status pasien diklasifikasikan menjadi 5, yaitu: $:^{1,5}$ 
Suspek/Pasien Dalam Pengawasan (PDP)

- Orang dengan Infeksi Saluran Pernapasan Akut (ISPA) yaitu demam $\left(\geq 38^{\circ} \mathrm{C}\right)$ atau riwayat demam; disertai salah satu tanda/ gejala penyakit pernapasan seperti: batuk/ sesak napas/sakit tenggorokan/pilek/ pneumonia ringan hingga berat DAN pada 14 hari terakhir sebelum timbul gejala memiliki riwayat perjalanan atau tinggal di negara/ wilayah yang melaporkan transmisi lokal;

- Orang dengan demam $\left(\geq 38^{\circ} \mathrm{C}\right)$ atau riwayat demam atau ISPA DAN pada 14 hari terakhir sebelum timbul gejala memiliki riwayat kontak dengan kasus terkonfirmasi atau probable COVID-19;

- Orang dengan ISPA berat/pneumonia berat yang membutuhkan perawatan di rumah sakit DAN tidak ada penyebab lain berdasarkan manifestasi klinis yang meyakinkan.

\section{Orang Dalam Pemantauan (ODP)}

- Orang yang mengalami demam $\left(\geq 38^{\circ} \mathrm{C}\right)$ atau riwayat demam; atau gejala gangguan sistem pernapasan seperti pilek/sakit tenggorokan/batuk DAN tidak ada penyebab lain berdasarkan manifestasi klinis yang meyakinkan DAN pada 14 hari terakhir sebelum timbul gejala memiliki riwayat perjalanan atau tinggal di negara/wilayah yang melaporkan transmisi lokal;

- Orang yang mengalami gejala gangguan sistem pernapasan seperti pilek/sakit tenggorokan/batuk DAN pada 14 hari terakhir sebelum timbul gejala memiliki riwayat kontak dengan kasus konfirmasi COVID-19.

\section{Orang Tanpa Gejala (OTG)}

Orang yang tidak bergejala dan memiliki risiko tertular dari orang terkonfirmasi COVID-19. Orang tanpa gejala merupakan kontak erat dengan kasus terkonfirmasi COVID-19. Kontak Erat adalah orang yang melakukan kontak fisik atau berada dalam ruangan atau berkunjung (dalam radius 1 meter dengan kasus PDP atau terkonfirmasi) dalam 2 hari sebelum kasus timbul gejala dan hingga 14 hari setelah kasus timbul gejala. Orang yang termasuk kontak erat yaitu:

- Petugas kesehatan yang memeriksa, merawat, mengantar, dan membersihkan ruangan di tempat perawatan kasus tanpa menggunakan APD sesuai standar;

- Orang yang berada dalam suatu ruangan yang sama dengan kasus (termasuk tempat kerja, kelas, rumah, acara besar) dalam 2 hari sebelum kasus timbul gejala dan hingga 14 hari setelah kasus timbul gejala;

- Orang yang bepergian bersama (radius 1 meter) dengan segala jenis alat angkut/ kendaraan dalam 2 hari sebelum kasus timbul gejala dan hingga 14 hari setelah kasus timbul gejala.

\section{Kasus Konfirmasi}

Pasien yang terinfeksi COVID-19 dengan hasil pemeriksaan tes positif melalui pemeriksaan PCR.

\section{Komorbiditas}

Penyakit penyerta (komorbid) yang menggambarkan kondisi bahwa ada penyakit lain yang dialami selain dari penyakit utamanya (misal, diabetes mellitus, hipertensi, kanker).

\section{Tatalaksana/Penanggulangan}

Penanganan COVID-19 di Indonesia menggunakan Rapid Test (RT) Antibodi dan/atau Antigen pada kasus kontak dari pasien positif. Rapid Test Antibodi/Rapid Test Antigen dapat juga digunakan untuk deteksi kasus ODP dan PDP pada wilayah yang tidak mempunyai fasilitas untuk pemeriksaan Reverse TranscriptionPolymerase Chain Reaction (RT-PCR) atau tidak mempunyai media pengambilan spesimen (swab dan Virus Transport Media/VTM). Pemeriksaan Rapid Test Antibodi dan/atau Rapid Test Antigen hanya merupakan screening awal, hasil pemeriksaan Rapid Test Antibodi dan/atau Rapid Test Antigen harus tetap dikonfirmasi dengan menggunakan RT-PCR. Pasien akan dibedakan menjadi 3 kelompok di fasilitas kesehatan, yaitu: ${ }^{1,5}$

\section{Kelompok OTG}

Kelompok ini akan melalui pemeriksaan RT Antibodi,jika pemeriksaan pertama menunjukkan hasil:

- Negatif, tatalaksana selanjutnya adalah karantina mandiri dengan menerapkan 
Pola Hidup Bersih dan Sehat (PHBS) dan physical distancing; kemudian diperiksa ulang pada hari ke-10. Jika hasil pemeriksaan ulang positif, maka dilanjutkan dengan pemeriksaan RT-PCR sebanyak 2 kali selama 2 hari berturut-turut, apabila tersedia fasilitas pemeriksaan RT-PCR.

- Positif, tatalaksana selanjutnya adalah karantina mandiri dengan menerapkan PHBS dan physical distancing; Pada kelompok ini juga akan dikonfirmasi dengan pemeriksaan RT-PCR sebanyak 2 kali selama 2 hari berturut-turut, apabila tersedia fasilitas pemeriksaan RT-PCR.

\section{Kelompok ODP}

Kelompok ini akan melalui pemeriksaan RT Antibodi dan jika pemeriksaan pertama menunjukkan hasil:

- Negatif, tatalaksana selanjutnya adalah isolasi diri di rumah dengan menerapkan PHBS dan physical distancing; pemeriksaan ulang pada hari ke-10. Jika hasil pemeriksaan ulang positif, maka dilanjutkan dengan pemeriksaan RT-PCR sebanyak 2 kali selama 2 hari berturut-turut, apabila tersedia fasilitas pemeriksaan RT-PCR.

- Positif, tatalaksana selanjutnya adalah isolasi diri di rumah dengan menerapkan PHBS dan physical distancing; Pada kelompok ini juga akan dikonfirmasi dengan pemeriksaan RTPCR sebanyak 2 kali selama 2 hari berturutturut, apabila tersedia fasilitas pemeriksaan RT-PCR.

\section{Kelompok PDP}

Kelompok ini akan melalui pemeriksaan RT Antibodi dan jika pemeriksaan pertama menunjukkan hasil:

- Negatif, tatalaksana selanjutnya adalah isolasi diri rumah dengan menerapkan PHBS dan physical distancing; pemeriksaan ulang pada hari ke-10. Jika hasil pemeriksaan ulang positif, maka dilanjutkan dengan pemeriksaan RT-PCR sebanyak 2 kali selama 2 hari berturut-turut. Apabila mengalami perburukan gejala, lakukan perawatan di rumah sakit.

- Positif, tatalaksana selanjutnya adalah isolasi diri di rumah (gejala ringan), isolasi di rumah sakit darurat (gejala sedang), atau isolasi di rumah sakit rujukan (gejala berat); Pada kelompok ini juga akan dikonfirmasi dengan pemeriksaan RT-PCR sebanyak 2 kali selama 2 hari berturut-turut.

\section{Tatalaksana Pengobatan Pasien COVID-19}

Pasien dengan hasil pemeriksaan RT Antibodi positif yang dirawat di Rumah Sakit akan diberikan obat sebagai berikut, sampai hasil pemeriksaan spesifik terbukti negatif: ${ }^{5}$ antibiotik empiris: makrolide yaitu, azitromicin 1x500 mg selama 5-6 hari atau, fluoroquinolone yaitu, Levofloxacin $1 \times 650 \mathrm{mg}$ selama 6 hari; antivirus; vitamin $\mathrm{C}$ dosis tinggi selama 14 hari; chloroquine phosphate dapat ditambahkan pada pasien dengan kondisi berat; terapi simptomatik sesuai dengan gejala; hepatoprotektor bila SGOT dan SGPT meningkat; Obat-obat lain sesuai penyakit penyerta. Pasien dengan hasil pemeriksaan positif yang dirawat di rumah dan di fasilitas khusus/RS darurat maka obat diberikan secara oral. Dilarang menggunakan kortikosteroid, kecuali pada kasus dengan komorbid tertentu. Untuk pasien anak dosis obat disesuaikan. ${ }^{5}$

\section{Indikasi Pasien yang Memerlukan Ventilator Mekanik.}

Pada prinsipnya seluruh pasien yang masuk di RS Rujukan adalah PDP yang memenuhi kriteria salah satu sebagai berikut: ${ }^{5}$ gagal napas berdasarkan pemeriksaan analisis gas darah, apabila tidak bisa dilakukan analisis gas darah, saturasi oksigen $<90 \%$, penurunan kesadaran, tanda- tanda sepsis atau sepsis.

\section{Tatalaksana Pemulangan Pasien COVID-19}

Pasien yang dirawat dengan diagnosa infeksi COVID-19 dapat dipulangkan apabila hasil pemeriksaan RT-PCR negatif 2 kali berturut-turut dalam selang waktu 2 hari. Apabila tidak tersedia pemeriksaan RT-PCR, maka pemulangan pasien COVID-19 didasari oleh: ${ }^{5}$ klinis perbaikan tanpa oksigen dan radiologis perbaikan, dan perbaikan 
Tabel1. Tata Kelola Karantina ${ }^{5}$

\begin{tabular}{|c|c|c|c|}
\hline Bentuk Karantina & Karantina Rumah & $\begin{array}{l}\text { Karantina Fasilitas Khusus/ } \\
\text { Rumah Sakit Darurat } \\
\text { COVID-19 }\end{array}$ & Karantina Rumah Sakit \\
\hline Status & $\begin{array}{l}\text { OTG, ODP, PDP Gejala } \\
\text { Ringan }\end{array}$ & $\begin{array}{l}\text { ODP usia }>60 \text { tahun } \\
\text { dengan penyakit penyerta } \\
\text { yang terkontrol, } \\
\text { PDP Gejala Sedang, } \\
\text { mandiri, tanpa sesak } \\
\text { napas/tanpa pneumonia } \\
\text { Pasien terkonfirmasi } \\
\text { COVID-19, tanpa } \\
\text { penyakit lain dan tanpa } \\
\text { sesak napas/tanpa } \\
\text { pneumonia }\end{array}$ & PDP Gejala Berat \\
\hline Tempat & $\begin{array}{l}\text { Rumah sendiri/fasilitas } \\
\text { sendiri }\end{array}$ & $\begin{array}{l}\text { Tempat yang disediakan } \\
\text { Pemerintah (Rumah sakit daru- } \\
\text { rat COVID-19) }\end{array}$ & Rumah Sakit \\
\hline Pengawasan & $\begin{array}{l}\text { Dokter, perawat, } \\
\text { dan/atau tenaga } \\
\text { kesehatan lain } \\
\text { Dapat dibantu oleh } \\
\text { Bhabinkabtibnas, } \\
\text { Babinsa, dan/atau } \\
\text { Relawan }\end{array}$ & $\begin{array}{l}\text { Dokter, perawat, dan/atau } \\
\text { tenaga kesehatan lain }\end{array}$ & $\begin{array}{l}\text { Dokter, perawat, dan/atau } \\
\text { tenaga kesehatan lain }\end{array}$ \\
\hline Pembiayaan & $\begin{array}{ll}\text { - } & \text { Mandiri } \\
\text { - } & \text { Pihak lain yang } \\
\text { bisa membantu } \\
\text { (filantropi) }\end{array}$ & $\begin{array}{l}\text { Pemerintah: BNPB, } \\
\text { Gubernur, Bupati, Walikota, } \\
\text { Camat, dan Kades } \\
\text { - Sumber lain }\end{array}$ & $\begin{array}{l}\text { Pemerintah: BNPB, } \\
\text { Gubernur, Bupati, } \\
\text { Walikota, Camat, dan } \\
\text { Kades } \\
\text { - Sumber lain }\end{array}$ \\
\hline Monitoring dan & Dilakukan oleh Dinas & Dilakukan oleh Dinas & Dilakukan oleh Dinas \\
\hline Evaluasi & Kesehatan setempat & Kesehatan setempat & Kesehatan setempat \\
\hline
\end{tabular}

klinis dengan saturasi oksigen lebih 95\%.

\section{Pencegahan}

Mekanisme transmisi COVID-19 saat ini masih belum jelas, sehingga pencegahan menjadi sangat penting dalam menghadapi pandemik ini. Sampai saat ini pencegahan dibedakan menjadi pencegahan pada orang sehat dan pencegahan penularan sesuai dengan status pasien. Pada orang sehat, pencegahan berupa: ${ }^{1}$ menjaga kebersihan personal dan lingkungan, meningkatkan imunitas dan mengendalikan komorbid, pembatasan interaksi fisik dan pembatasan sosial (physical contact/physical distancing/social distancing), menerapkan etika batuk dan bersin.
Sedangkan pencegahan penularan berupa karantina. Karantina dilakukan sesuai dengan tempat seperti yang dijelaskan pada Tabel 2.1. Penularan dapat terjadi dari manusia ke manusia, dan juga risiko penyebaran lewat airborne selama prosedur medis yang menghasilkan aerosol dalam keadaan tertentu. Pasien yang terinfeksi COVID-19 berisiko mengalami gagal napas, sehingga perlu untuk dirawat di cricital care unit. Pasien harus segera diisolasi di ruang isolasi airborne (misal, kamar tunggal, tekanan negatif, pertukaran udara teratur) jika tersedia. Apabila tidak tersedia ruang isolasi airborne, pasien harus ditempatkan di ruang tunggal dengan pintu tertutup. 


\section{Peran Dokter Anestesi dalam Penatalaksanaan COVID-19}

Manifestasi klinis COVID-19 bervariasi, dengan sebagian besar pasien memiliki gejala saluran pernapasan. Penelitian pada 1.099 pasien COVID-19 menunjukkan bahwa 19\% pasien mengalami sesak napas, $41 \%$ membutuhkan suplementasi oksigen, $5 \%$ menjadi sakit kritis, dan $2,3 \%$ membutuhkan ventilasi mekanik invasif. ${ }^{6}$ Dokter anestesi berperan pada garis pertahanan pertama di IGD untuk melakukan resusitasi, juga pada saat melakukan tindakan di ruang operasi serta sebagai benteng terakhir saat menangani pasien suspek/terkonfirmasi COVID-19 dengan gagal napas di ruang perawatan intensif. Dengan demikian dokter spesialis Anestesi mempunyai peranan yang sangat penting dalam penatalaksanaan pasien Covid-19.

Tenaga kesehatan yang terpapar COVID-19 berisiko terinfeksi apabila tidak menggunakan APD sesuai standar, sehingga pengetahuan APD bagi dokter anestesi menjadi sangat penting.3 Saat ini, panduan WHO dan Centers for Disease Control and Prevention (CDC) untuk prinsip perlindungan tenaga kesehatan selama prosedur medis yang menghasilkan aerosol pada

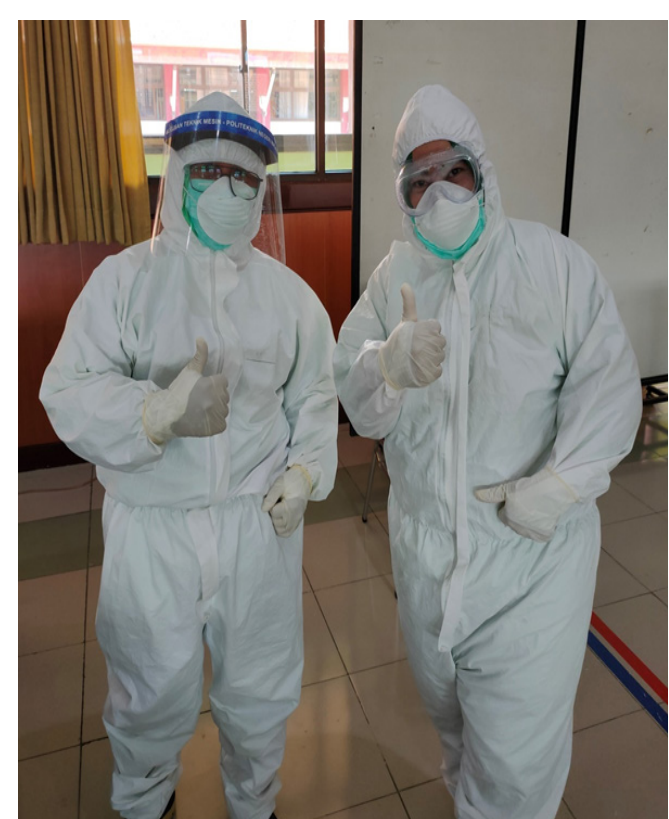

Gambar1. Contoh penggunaan APD menggunakan N95 untuk melindungi droplet/airborne pasien suspek/terkonfirmasi COVID-19 yaitu komunikasi yang jelas, meminimalkan petugas di dalam ruangan selama prosedur, penggunaan APD yang tepat, serta menghindari prosedur yang menghasilkan aerosol dalam jumlah besar. ${ }^{3}$

Alat Pelindung Diri (APD) yang direkomendasikan untuk kontak dengan critically ill patients dengan suspek/terkonfirmasi COVID-19 meliputi gaun tahan air, sarung tangan, pelindung mata, pelindung wajah full face, masker N95, pelindung rambut, serta sepatu khusus yang ditunjukkan pada gambar 1 . Sarung tangan yang direkomendasikan adalah sarung tangan lengan panjang untuk mencegah pajanan pada pergelangan tangan apabila ujung sarung tangan pendek terlipat. Tetapi apabila tidak ada sarung tangan lengan panjang, dapat menggunakan perekat secara vertikal agar tidak ada celah antara sarung tangan dengan gaun. Pelindung mata harus dapat melindungi dari samping atau goggles. Pelindung wajah full face dapat melindungi mata dan menghindari kontaminasi pada wajah maupun saluran pernapasan. Sepatu khusus yang digunakan harus kedap terhadap cairan dan dapat didekontaminasi, karena beberapa penutup sepatu sekali pakai dapat meningkatkan risiko kontaminasi diri saat

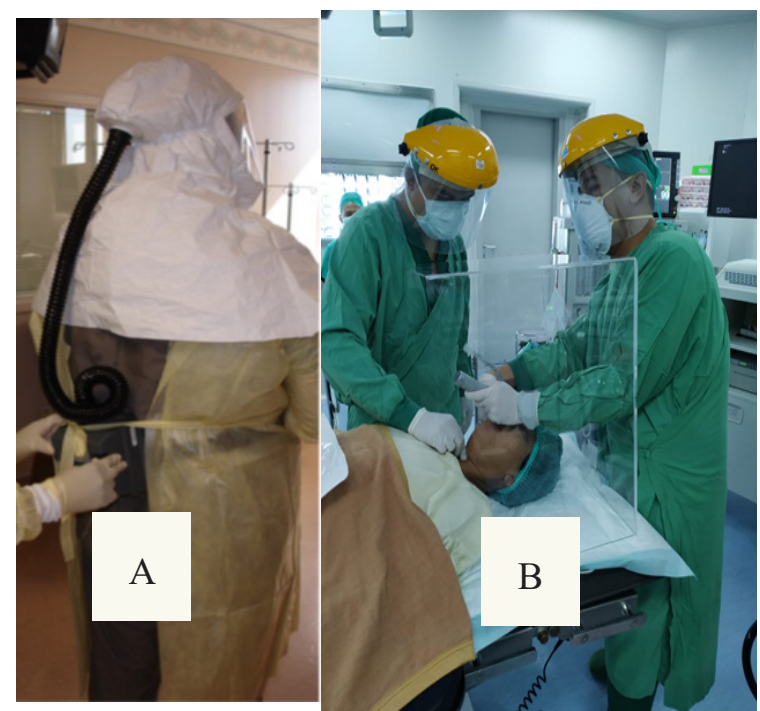

Gambar 2. Contoh penggunaan APD menggunakan PAPR yang disempurnakan (A), menggunakan masker N95 dan aerosol box (B), untuk melindungi droplet/airborne pada saat intubasi pasien suspek/ terkonfirmasi COVID-19. 
dilepas. Selain itu hand hygiene harus selalu diterapkan setelah melepas APD maupun apabila tangan menyentuh APD tanpa sarung tangan. Terdapat kontroversi yang berkaitan dengan penggunaan N95 dibandingkan dengan powered air purifying respirator (PAPR) untuk prosedur yang menghasilkan aerosol. ${ }^{9}$ Meskipun PAPR memiliki faktor perlindungan yang lebih tinggi dibandingkan dengan masker N95, tidak ada bukti pasti bahwa PAPR menurunkan kemungkinan penularan virus yang dapat menular melalui airborne. Meskipun demikian, PAPR mungkin lebih nyaman saat digunakan untuk resusitasi yang berkepanjangan dan kemungkinan untuk lepas lebih kecil ketika menangani pasien yang gelisah. Powered air purifying respirator dengan penutup kepala dan leher yang ditunjukkan pada Gambar 2. juga dapat memberikan perlindungan tambahan terhadap kontaminasi dibandingkan dengan N95. Mengingat bahwa petugas kesehatan dapat terinfeksi selama resusitasi pasien dengan SARS meskipun menggunakan masker N95, penggunaan PAPR menjadi rekomendasi pada saat resusitasi pasien suspek/terkonfirmasi COVID-19.

Terdapat laporan yang belum terkonfirmasi bahwa penularan dapat terjadi sebelum munculnya manifestasi klinis, sehingga sulit untuk mengidentifikasi dan mengisolasi pasien yang terinfeksi virus. ${ }^{4}$ Oleh karena itu, triage, pengenalan awal, dan isolasi segera pasien suspek/terkonfirmasi COVID-19 menjadi sangat penting agar dapat meminimalkan prosedur yang menghasilkan aeorosol selama general anesthesia (GA), seperti bag mask ventilation, open airway suctioning, dan endotracheal intubation. Selama outbreak SARS, intubasi merupakan salah satu faktor risiko tunggal untuk super-spreading nosocomial outbreaks yang mempengaruhi banyak tenaga kesehatan di Hong Kong dan Guangzhou, China. Dengan demikian, agar mengurangi risiko penularan virus nosokomial disarankan untuk meminimalkan manajemen airway pada pasien suspek/terkonfirmasi COVID-19.

Beberapa pertimbangan diberikan untuk membantu mempersiapkan manajemen airway pasien suspek/terkonfirmasi COVID-19. ${ }^{8}$ Tindakan pencegahan yang dapat dilakukan oleh dokter anestesi dapat berupa meminimalkan prosedur yang menghasilkan aerosol selama prosedur GA yang dapat mengurangi pajanan terhadap ekskresi pernapasan pasien, serta risiko penularan virus perioperatif ke tenaga kesehatan dan pasien lain. ${ }^{4}$ Untuk mengurangi tindakan yang memanipulasi airway, regional anesthesia (RA) dapat dipertimbangkan setiap kali merencanakan operasi pasien suspek/ terkonfirmasi COVID-19, ataupun pasien yang memiliki risiko infeksi. Regional anesthesia memiliki keuntungan dalam perawatan fungsi pernapasan, penghindaran aerosolisasi, dan transmisi virus. ${ }^{4}$ Keuntungan utama RA pada pasien dengan infeksi pernapasan karena virus

Tabel 2. Early warning score COVID-19 (COVID-19 EWS) ${ }^{2,16,}$

\begin{tabular}{lll}
\hline Parameter & Penilaian & Nilai \\
\hline Pneumonia pada CT Scan & ada & 5 \\
Riwayat kontak dengan pasien & ada & 5 \\
positif COVID-19 & ada & 3 \\
Demam & $\geq 3.8^{\circ}$ C sejak gejala dimulai & 1 \\
Suhu maksimum & $\geq 44$ tahun & 1 \\
Usia & Laki-Laki & 1 \\
Jenis Kelamin & $\geq 1$ gejala & 1 \\
Gejala gangguan pernafasan & & \\
(Batuk, dahak, sesak, dll) & $\geq 5.8$ & 1 \\
Rasio neutrofil-limfosit & \multicolumn{2}{c}{ Kecurigaan tinggi jika nilai $>10$} \\
\hline
\end{tabular}


yaitu menghindari instrumentasi airway dan pasien batuk selama intubasi atau ekstubasi. sehingga mengurangi risiko penularan kepada tenaga kesehatan melalui pembentukan aerosol dan dispersi partikel virus yang terkait. Secara umum, RA memiliki efek yang lebih sedikit pada fungsi dan dinamika pernapasan dibandingkan dengan GA. Secara teori, perawatan fungsi pernapasan ini dapat mengurangi komplikasi paru pasca operasi pada pasien COVID-19 yang mungkin telah mengalami penurunan fungsi pernapasan karena pneumonia terkait COVID-19 atau acute respiratory distress syndrome (ARDS). ${ }^{4}$

\section{Tatalaksana Anestesi pada Operasi Obstetri dengan Covid-19}

Jumlah kasus Covid-19 terus meningkat secara eksponensial di berbagai belahan dunia, termasuk jumlah wanita hamil pada semua usia kehamilan yang terinfeksi Covid-19 juga mengalami peningkatan. Resiko terbesar wanita hamil yang terinfeksi Covid-19 adalah ibu hamil dalam persalinan dan ibu yang sakit akut. ${ }^{11}$ Wanita hamil mungkin lebih rentan terhadap infeksi saluran pernapasan dan pneumonia dibandingkan dengan wanita tidak hamil, karena pada wanita hamil terjadi adaptasi fisiologis kehamilan, seperti edema mukosa saluran pernapasan, peningkatan diafragma, dan peningkatan konsumsi oksigen, serta adanya perubahan imunologisi terkait kehamilan. Perubahan adaptif ini juga membuat wanita kurang toleran terhadap hipoksia. ${ }^{13}$

Virus corona merupakan ancama kesehatan yang utama pada masarakat, dan pertumbuhan penyakit ini eksponensial. Sehingga sangat masuk akal menganggap bahwa sebagian besar wanita hamil yang datang untuk perawatan berpotensi terinfeksi covid tanpa menimbulkan gejala. Telah diketahui bahwa infeksi Covid-19 sering tanpa gejala oleh karena itu semua wanita hamil di daerah dengan prevalensi Covid-19 yang tinggi harus dipertimbangkan sebagai penderita Covid-19. ${ }^{12}$ Oleh karena itu sebelum dilakukan tindakan anestesi sangat perlu dilakukan deteksi dini untuk infeksi Covid-19 kepada semua wanita hamil yang akan dilakukan seksio sesarea. Deteksi dini terhadap infeksi Covid-19 bisa dilakukan dengan cara pemeriksaan dengan Rapid Test (RT) Antibodi dan/atau Antigen, terutama wilayah yang tidak mempunyai fasilitas untuk pemeriksaan Reverse TranscriptionPolymerase Chain Reaction (RT-PCR) atau tidak mempunyai media pengambilan spesimen (swab dan Virus Transport Media/VTM). ${ }^{5,1}$ Metode lain yang diperkenalkan untuk deteksi dini adalah penggunaan early warning score (EWS) yang dikembangkan di Universitas Zhejiang. EWS ini menggunakan beberapa parameter yang cukup sering ditemukan pada penderita COVID-19, yaitu adanya tanda pneumonia pada CT Scan, adanya riwayat kontak dengan pasien positif COVID-19, adanya demam, suhu maksimum $>3.8^{\circ} \mathrm{C}$ sejak gejala dimulai, jenis kelamin lakilaki, usia $>40$ tahun, adanya beberapa gejala gangguan pernafasan dan rasio neutrofil-limfosit (Tabel 2). ${ }^{2,16}$

Berdasarkan pedoman Komisi Kesehatan Nasional China, riwayat kontak disebut positifjika seseorang dalam 14 hari terakhir memiliki riwayat bepergian ke Wuhan, riwayat bertemu dengan orang yang sakit setelah berkunjung ke Wuhan, riwayat kontak dengan pasien COVID-19 positif dan riwayat bepergian ke daerah dengan kasus COVID-19 yang terkonfirmasi. ${ }^{16}$ Penggunaan COVID-19 EWS memiliki training dataset 0,956 dan validate dataset 0,966. COVID-19 EWS ini dapat sangat membantu karena umumnya dapat digunakan dimana saja. Parameter pertama (pemeriksaan CT-scan) memang tidak tersedia di seluruh wilayah Indonesia, tetapi hal ini dapat disiasati dengan menggunakan foto rontgen thorax yang lebih umum tersedia. Pada 8\% pasien dengan pneumonia, terdapat gambaran pneumonia pada foto rontgen thorax dan CT scan thorax. Hanya $4 \%$ pasien dengan gambaran foto rontgen thorax pneumonia dan tidak terdapat gambaran pneumonia pada CT scan. Belum diketahui seberapa jauh hal ini mempengaruhi sensitivitas dan spesifisitas pemeriksaan, tetapi ini dapat menjadi solusi yang menjanjikan. ${ }^{16}$

Permasalahan lain dari sistem ini adalah bahwa COVID-19 EWS belum dikonfirmasi untuk penggunaannya pada populasi di Indonesia. Namun, mengingat adanya kesamaan ras sebagai 
ras mongoloid, maka COVID-19 EWS berpotensi besar memberikan manfaat yang serupa. Fasilitas rRT-PCR untuk melakukan deteksi dini di Indonesia masih terbatas, sehingga EWS dapat digunakan sebagai indikasi untuk melakukan isolasi pasien, penelusuran kontak dan prioritas pemeriksaan rRT-PCR. ${ }^{16}$ Wanita dengan gejala COVID-19 harus segera diisolasi dalam satu ruangan untuk deteksi dini, dan pergerakan pasien di seluruh fasilitas harus dibatasi. Kasus yang dikonfirmasi harus dirawat di ruang tekanan negatif atau ruang isolasi. Wanita dengan tandatanda penyakit kritis harus segera dipindahkan ke unit perawatan intensif atau kritis dengan tekanan negatif atau setara. Rumah sakit harus membangun ruang operasi tekanan negatif khusus untuk wanita hamil yang harus melahirkan dengan infeksi COVID-19 yang dikonfirmasi, dan ruang isolasi tekanan negatif neonatal khusus untuk bayi yang baru lahir harus didirikan. Idealnya, kamarkamar ini akan berdekatan satu sama lain, untuk membatasi lalu lintas dan pergerakan ODP/PDP maupun wanita dan bayi yang telah diketahui terinfeksi covid-19. Kunjungan keluarga juga perlu dibatasi untuk mencegah penularan kepada keluarga dekat. ${ }^{17}$ Wanita hamil dengan dugaan COVID-19 maupun konfirmasi COVID-19 yang akan dilakukan tindakan seksio sesaria perhatian kusus yang harus dilakukan antara lain:11,16,17,18,19

- Pusat pelayan kesehatan harus menstandarkan penapisan, penerimaan, dan manajemen semua wanita hamil yang terinfeksi COVID-19, sesuai dengan pedoman lokal, nasional, dan internasional; masyarakat harus diberitahu tentang risiko hasil kehamilan di era COVID-19.

- Fasilitas layanan kesehatan harus menyediakan APD yang memadai untuk memenuhi persyaratan tindakan bagi petugas.

- Semua petugas layanan kesehatan harus dilatih dalam strategi pengendalian dan pencegahan infeksi, dan dalam prosedur untuk mengenakan serta melepas alat pelindung diri (APD)

- Pasien harus menggunakan masker, dan semua wanita hamil harus ditanyai apakah mereka memiliki riwayat perjalanan ke daerah endemis atau kontak dengan orang lain yang dikonfirmasi memiliki COVID-19 dan harus diskrining untuk manifestasi klinis pneumonia COVID-19.

- Wanita hamil dengan dugaan infeksi COVID-19 harus menjalani pemeriksaan pencitraan paru (CXR, CT) dan tes diagnostik untuk COVID-19 sesegera mungkin.

- Untuk wanita hamil dengan infeksi COVID-19 yang dikonfirmasi, pemeriksaan rutin bila memungkinkan dilakukan di ruang isolasi tekanan negatif, dan petugas kesehatan harus mengenakan pakaian pelindung, masker N95, kacamata, dan sarung tangan sebelum kontak dengan pasien

- Posisikan lateral-decubitus untuk memperbaiki oksigenasi uteroplasenta.

- Oksigenasi: sebagian besar wanita hamil membutuhkan $\mathrm{SpO}_{2}>95 \%$, untuk mempertahankan oksigenasi janin yang memadai. Oksigen harus diberikan segera untuk mencegah hipoksemia dan mengurangi kerja pernapasan (work of breathing) dan mencegah gagal napas maupun henti nafas. Gunakan highflownasal canulla (HFNC) atau non-invasive mechanical ventilation (NIV) pada pasien dengan ARDS atau efusi paru luas. HFNC lebih disarankan dibandingkan NIV. Intubasi endotracheal diperlukan jika maternal mengalami kondisi berikut: pasien menjadi gelisah atau kesadarannya menurun, pasien merasa tidak nyaman, upaya napas meningkat $>30 \mathrm{kali} / \mathrm{menit}$, peningkatan nadi $>120 \mathrm{kali} / \mathrm{menit}$, penggunaan otot-otot bantu pernapasan berlebihan. Dari penilaian oksigenasi dengan menggunakan $\mathrm{HFNC}>30$ liter/menit atau NIV dan $\mathrm{FiO}_{2}>60 \%$ tidak dapat menjaga $\mathrm{SpO}_{2}>92 \%$ (95\% dengan komorbid).

- Terapi antimikroba: untuk wanita hamil yang dicurigai atau dikonfirmasi infeksi bakteri sekunder, pengobatan antibakteri harus dimulai dengan antimikroba spektrum luas. Antibiotik harus disesuaikan dengan hasil sensitivitas obat.

- Manajemen cairan: pasien yang sakit kritis tanpa syok harus dirawat dengan tindakan manajemen cairan konservatif, ketika syok septik terjadi, resusitasi volume dan norepinefrin digunakan untuk 
mempertahankan tekanan darah arteri ratarata (MAP) pada $60 \mathrm{~mm} \mathrm{Hg}$ atau lebih. Pembatasan resusitasi cairan dilakukan pada pasien dengan edema paru.

- Hemodialisis: diperlukan jika terjadi gagal ginjal akut yang parah akibat sepsis, atau terjadi ketidakseimbangan elektrolit yang sangat mengancam jiwa dan tidak responsif terhadap manajemen konservatif.

- Disarankan bahwa dokter spesialis kebidanan \& kandungan, ahli neonatologi, ahli anestesi dan profesional medis lainnya bersama-sama mengelola wanita hamil dengan pneumonia COVID-19 dan secara ketat mencegah infeksi silang. Staf medis yang merawat pasien ini harus memonitor diri mereka sendiri setiap hari untuk manifestasi klinis seperti demam dan batuk. Jika pneumonia infeksi COVID-19 terjadi, staf medis juga harus dirawat di bangsal isolasi

- Pada wanita hamil dengan infeksi COVID-19 yang membutuhkan persalinan sesar, tehnik anestesi pilihan utama adalah anestesi regional (epidural dan atau Spinal). Apabila seksio sesarea emergensi pilihan anestesi dengan tehnik Rapid Sequence Spinal Anesthesia (RSSA)

- Operasi caesar harus dilakukan oleh dokter kandungan senior, untuk meminimalkan kemungkinan komplikasi

- Anestesi Umum dengan cara Rapid Sequence Intubation (RSI) dengan balon endo tracheal tube (ETT) harus dikembangkan, merupakan pilihan alternatif apabila: gagal dengan tehnik anestesi regional, ada kontraindikasi dengan tehnik anestesi regional dan pada maternal yang direncanakan seksio sesarea darurat mengalami desaturasi (saturasi oksigen menurun hingga $\leq 93 \%$ ).

- Selama melakukan tindakan, semua petugas harus menggunakan APD yang tepat sesuai standar, meminimalkan petugas di dalam ruangan selama prosedur, menghindari prosedur yang menghasilkan aerosol dalam jumlah besar.

Lakukan kebersihan tangan yang tepat sebelum dan sesudah semua prosedur. apabila dengan tehnik anestesi regional ada kontraindikasi, gagal dengan tehnik anestesi regional atau maternal mengalami desaturasi (saturasi $<93 \%$ ) maka tehnik anestesi alternatifnya adalah dengan anestesi umum dengan perhatian khusus untuk pencegahan penularan infeksi. Tindakan tehnik anestesi umum, akan menimbulkan terjadinya aerosol yang besar yaitu pada saat: bag mask ventilation, Open airway suctioning, intubasi endotrakhea,dan pada saat ektubasi. Karena pada saat dilakukan tindakan tersebut menghasilkan aerosol dalam jumlah yang besar, maka prosedur yang harus dilakukan adalah: ${ }^{19,20}$

- Melindungi petugas kesehatan dengan menggunakan APD adalah prioritas pertama, karena petugas kesehatan adalah garis pertahanan utama untuk pasien ini, dan pasien yang akan datang.

- Tindakan dilakukan di ruangan dengan tekanan negatip.

- Minimalisasi jumlah petugas yang ada dalam ruangan tersebut pada saat dilakukan tindakan.

- Sebelum prosedur dimulai, pastikan semua peralatan siap: peralatan monitoring standar, obat-obatan sudah lengkap, jalur infus sudah terpasang dan bias mengalir baik. Pastikan, peralatan intubasi termasuk mesin anestesi dan peralatan hisap tersedia lengkap dan berfungsi baik.

- Tindakan dilakukan oleh tenaga yang paling menguasai semua.

- Peralatan yang tidak dibutuhkan dikeluarkan dari ruangan untuk mencegah kontaminasi silang.

- Hindari intubasi sadar dengan fiberoptik laringoskop (karena risiko batuk dan aerosol). Apabila memiliki videolaringoskop gunakan alat ini untuk meminimalkan paparan yang dekat antara ahli anestesi dan aerosol pernapasan pasien.

- Daerah pasien yang akan menimbulkan aerosol (sekitar muka pasien), ditutup dengan selapis plastik transparan atau ditutup dengan aerosol box.

- Pastikan filter Heat and Moisture Exchanger (HME) ditempatkan di antara sungkup muka dan sirkuit pernapasan

- Preoksigenasi cepat dicapai dengan empat napas kapasitas maksimal dengan oksigen 
$100 \%$.

- Jika diperlukan ventilasi manual, gunakan volume tidal kecil saja (4-8 ml/kgBB)

- Penggunaan high-flow nasal oxygenation (HFNO) dan masker CPAP atau BiPAP harus dihindari karena risiko yang lebih besar dari generasi aerosol.

- Semua peralatan jalan nafas harus didekontaminasi dan didesinfeksi sesuai dengan kebijakan rumah sakit dan pabrik yang sesuai.

- Pastikan semua peralatan kotor ditempatkan di tempat sampah yang diberi label dengan tepat.

- Lepaskan sarung tangan luar sebelum menyentuh ruang yang mungkin disentuh oleh orang lain.

- APDdilepassesuaiprosedur,didalamareayang diperuntukkan untuk melepaskan APD kotor.

- Setelah melepas peralatan pelindung, hindari menyentuh rambut atau wajah sebelum mencuci tangan.

- Lakukan kebersihan tangan sebelum dan sesudah semua prosedur.

\section{Simpulan}

Coronavirus Disease 2019 (COVID-19) merupakan masalah kesehatan dunia termasuk di Indonesia oleh karena itu deteksi dini terhadap pasien obstetri yang akan dilakukan tindakan operasi sangat diperlukan. Tenaga kesehatan yang terpapar berisiko terinfeksi apabila tidak menggunakan APD sesuai standard, sehingga semua tenaga harus menggunakan APD sesuai levelnya. Dokter Anestesi dalam melaksanakan tindakan anestesi pada operasi obstetri harus mengutamakan keselamatan diri dengan cara menggunakan Alat perlindunga Diri (APD) yang tepat, mengurangi tindakan yang memanipulasi airway dan tindakan lain yang menimbulakan aerosol. Regional anestesi baik epidural dan atau spinal anestesi merupakan teknik anestesi pilihan utama untuk operasi obstetri dengan COVID-19. Tehnik anestesi umum hanya digunakan apabila gagal dengan tehnik regional anestesi,ada kontraindikasidengantehnik anestesiregional atau maternal mengalami desaturasi (saturasi $<93 \%$ ).

\section{Daftar Pustaka}

1. Kementerian Kesehatan Republik Indonesia (Kemenkes). 2020. Pedoman pencegahan dan pengendalian coronavirus disease (COVID19) $\neg$ Revisi ke-4. Direktorat Jenderal Pencegahan dan Pengendalian Penyakit (P2P).

2. Zhu N, Zhang D, Wang W, Li X, Yang B, Song $\mathrm{J}$, et al. A novel coronavirus from patients with pneumonia in China, 2019. N Engl J Med 2020; 382:727-33.

3. Peng PWH, Ho PL, Hota SS. Outbreak of a new coronavirus: what anaesthetists should know. Br. J Anaesth, 2020; 124 (5): 497-50.

4. Lie SA, Wong SWW, Wong LT, Wong TGL, Chong SY. Practical considerations for performing regional anesthesia: lessons learned from the COVID-19 pandemic. Can J Anesth. 2020

5. Gugus Tugas COVID-19. Pedoman penanganan cepat medis dan kesehatan masyarakat COVID-19 di Indonesia. Gugus Tugas Percepatan Penanganan COVID-19. 2020.

6. Guan WJ, Ni ZY, Hu Y, Liang WH, Qu CQ, He JX, et al. Clinical characteristics of coronavirus disease 2019 in China. N Engl J Med. 2020.

7. Kementerian Dalam Negeri (Kemendagri). Pedoman umum menghadapi PANDEMI COVID-19 bagi pemerintah daerah: pencegahan, pengendalian, diagnosis dan manajemen. Tim Kerja Kementerian Dalam Negeri Untuk Dukungan Gugus Tugas COVID-19. 2020

8. Centers for disease control and prevention (CDC). Interim infection prevention and control recommendations for patients with confirmed 2019 novel coronavirus (2019$\mathrm{nCoV}$ ) or persons under investigation for 2019-nCoV in healthcare settings. 2020 
9. Novak D. Why, where, and how PAPRs are being used in health care. In: Institute of Medicine. The Use and Effectiveness of Powered Air Purifying Respirators in Health Care: Workshop Summary. Washington, DC: The National Academies Press. 2015.

10. World Health Organization (WHO). Coronavirus disease (COVID-19) technical guidance: infection prevention and control/ WASH. 2020

11. Ashokka B, Loh MH, Tan CH, SU LL, Young BE, Lye DC, Biswas A, illanes SE, Choolani M. Care of the Pregnant woman with COVID-19 in labor and delivery: anesthesia, emergency cesarean delivery, differential diagnosis in the acutely ill parturient, care of the newborn, and protection of the healthcare personnel. American Journal of Obstetrics and Gynecology; 2020.

12. Breslin N, Baptiste C, Gyamfi-Bannerman C, Miller R, Martinez R, Bernstein K, et al. COVID-19 infection among asymptomatic and symptomatic pregnant women: Two weeks of confirmed presentations to an affiliated pair of New York City hospitals. American Journal of Obstetrics \& Gynecology; 2020.

13. Liu D, Li L, Wu X, Zheng D, Wang J, Yang L, Zheng C. Pregnancy and perinatal outcomes of women with coronavirus disease (COVID-19) Pneumonia: A preliminary analysis. AJR 2020; 215: 1-6.

14. Pokja infeksi saluran reproduksi perkumpulan obstetri dan ginekologi Indonesia. Rekomendasi penanganan infeksi virus corona (covid-19) pada maternal (hamil, bersalin dan nifas). . 2020

15. Wang C, Horby PW, Hayden FG, Gao GF. A novel coronavirus outbreak of global health concern. Lancet. 2020;395:40-3.

16. Arif SK, Muchtar F, Wulung NV. Buku pedoman penanganan pasien kritis Covid-19. Perhimpunan Dokter Spesialis Anestesi dan Terapi Intensif Indonesia (PERDATIN). Versi 1. 2020 .

17. Chen D, Yang H, Cao Y, Cheng W, Duan T, Fan $\mathrm{C}$, et al. Expert consensus for managing pregnant women and neonates born to mothers with suspected or confirmed novel coronavirus (COVID-19) infection. 2020.

18. COVID-19 guidance for anaesthesia and perioperative care providers. https://www. wfsahq.org/resources/coronavirus. World Federation of Societies of Anesthesiologists (WFSA). 2020.

19. Anaesthesia and caring for patients during the COVID-19 outbreak. Australian Society of Anaesthetists (ASA). 2020 